\title{
THE INFLUENCE OF TALENT MANAGEMENT ON ORGANISATIONAL PERFORMANCE IN BOSNIA \& HERZEGOVINA AS A DEVELOPING COUNTRY
}

\author{
Elvir Čizmić* \\ Azra Ahmic ${ }^{* *}$
}

Received: 28. 9. 2020

Review

Accepted: 11. 1. 2021

UDC 005.953(497.6)

DOI https://doi.org/10.30924/mjcmi.26.1.8

\begin{abstract}
In today's globalized, fast-changeable, and digitalized market, companies strongly need and seek talents, who, besides basic skills, possess higher levels, as well as the optimal mix of different competencies and qualifications. Attracting the best employees, developing and retaining them represents a crucial success factor for any firm and requires well-organized talent management. The purpose of this study is to analyze the influence of talent management, viewed through attracting, developing, and retaining talents, on organizational performance improvement

of talented managers, who work in companies in Bosnia and Herzegovina. The findings indicate that talent management has a positive statistically significant influence on observed organizational performance in companies in Bosnia and Herzegovina. Since talented managers are a key strategic resource, who lead organizations to accomplish excellent organizational performance, companies in developing countries need to tailor effective and customized talent management strategies, to achieve continuous improvement of organizational outcomes.
\end{abstract} in companies in Bosnia and Herzegovina. Data collection is based on a questionnaire, related to core elements of talent management and organizational performance (profitability and sales growth), with respondents from the population

Keywords: talent attracting, talent development, talent engagement, organizational performance

\section{INTRODUCTION}

Human resources development is a very important activity for any contemporary organization and the biggest challenge for every company is to find and retain talented staff for the right positions. The lack of a sufficient number of high-quality candidates represents an enormous difficulty for many companies, especially those that work in specific areas or industries. Manpower Group conducted the global survey in 2018

(including 43 countries; 39.195 employers) regarding talent shortage and found out that forty-five percent of employers in small and medium enterprises couldn't find the skills they need and for large organizations which have $250+$ employees, the percent of talent shortage was even higher (67\%) (ManpowerGroup, 2018).

Talent management is faced with many problems and challenges on macro and micro level of business, especially concerning

\footnotetext{
* Elvir Čizmić, PhD, Professor, School of Economics and Business University of Sarajevo, Trg oslobođenja - Alija Izetbegović 1, 71000 Sarajevo, Bosnia \& Herzegovina, E-mail: elvir.cizmic@efsa.unsa.ba

** Azra Ahmić, PhD, Brace Krso 3, Vogosca 71320, Bosnia \& Herzegovina, E-mail: azraahmic30@gmail.com
} 


\section{Journal of Contemporary Management Issues}

increased job mobility, changing workforce demographics with diminished labor pools, increased demands of talented workers to stay with a company, economic problems in many countries, expanded use of information and communicational technologies, and globalization. Constant training and employee development improve the work potential and bring huge benefits to organizations because they create a positive image of employee development in each organizational process (Fajčikova et al, 2016). The World Economic Forum's 2017 Report on Global Human Capital holds governments responsible for investment failures in creating better education opportunities, which contribute to higher-quality work throughout the length of entire careers (World Economic Forum, 2017). It is based on the competency idea and its definition of human capital, which incorporates social capital into the understanding of work effectiveness. This implies that organizations need to attract talented people, able to provide contacts with their social networks (Sparrow, 2019).

Within these macro challenges, organizations face the complex problems of how to acquire, develop and retain talents, required for successful and competitive work in the ever-changing business environment. In this kind of environment, the competitive advantage is created by talents, who are competent, committed, communicative, cooperative, experienced, technologically knowledgeable, efficient, productive, and astute. Human resources, as the most valuable resource of an organization, or a society in general, are extremely important for strategy formulation implementation. The Boston Consulting Group provides an estimate, in its talent report (Boston Consulting Group, 2018), that $57 \%$ of their respondents want to work abroad, which is considerably less, compared to earlier research, carried out in 2014. Global Talent Competitiveness Index (GTCI), which is constructed based on a country's ability to attract, develop, and retaining talents, shows that developed countries with a high income have leading positions, i.e. there is a high correlation between GDP and GTCI values (Lanvin \& Evans, 2017). These reports also point out that highly developed countries develop talent management programs, focused on retaining domestic talents, but also, simultaneously, reduce the need for foreign employees. Possible causes of this trend are excellent education, knowledge, and experience of the domestic talents, which fit the needs of local firms, as well as the orientation of less developed countries to keep their citizens, by developing specific retaining programs.

In discussions on talent management, a comparison amongst the developed and emerging markets is a specific subject (Morley, Scullion, Collings, \& Schuler, 2015). Additional research is required on talent management within emerging markets, given the complexity and intensity of its challenges (Horwitz, Budhwar, \& Morley, 2015). Human resource professionals, in practice, declare that multinational firms within emerging markets face "dubious educational qualifications, and cultural issues - such as lack of experience in teams and reluctance to take initiative or assume leadership roles", while the quality of applicants oscillates vastly, which makes appropriate talent selection a challenge (Guthridge, Komm, \& Lawson, 2008). With a widespread trend of low salaries throughout the entire economies, with a large concentration in certain industries and organizations, it is extremely hard for policymakers to take interventions and boost wages if it directly impacts on business competitiveness and burdens it with unbearable costs (Devins \& Gold, 2014). 
This article provides an empirical analysis of talent management and its influence on organizational performance in Bosnia and Herzegovina, as a developing country. Hence, the research question was formed: „Does talent management, in its core elements (talent attraction methods, proper talent development/learning, and talent engagement - as an essential part of talent retention), influence on accomplishing sales and profit growth, as desirable organizational performance?"

As the basis for answering the research question, a detailed literature review is presented in the following section, with the focus on the concept of talent, integrated talent management elements, organizational performance, and the relationship between talent management and organizational performance.

\section{LITERATURE REVIEW}

\subsection{Discussion of the concept of talent}

While in ancient times the term talent denoted the amount/unit of money or weight, today it is mostly associated with an individual's superior capabilities, skills, and high potential to do work faster, easier, better, and with visible results. The fourth industrial revolution brings about a new paradigm for understanding talent management, which becomes linked with knowledge management and the entrepreneurial systems, trying to create macro-level talent management, by using smart public governance.

The concept of talent has been gaining attention and focus by practitioners and researchers since the invention of the phrase "the war for talent", which has been introduced by McKinsey (Lynton \& Beechler, 2012; Kaliannan \& Narh Adjovu, 2015). In this context, there are differences in defining the term of talent, regarding its meaning and scope (i.e. top management, high-potential employees, all employees): ,, There does not exist a single or universal contemporary definition of talent in any one language; there are different organizational perspectives of talent” (Tansley, 2011).

Some of the recent definitions of talent are:

- "Talented workers are super-keepers or a small group of individuals, about $3 \%$ of the organization's employees, who can inspire others to attain superior accomplishment and embody the creed, core competencies and values of their organization" (Berger \& Berger, 2011);

- Kaewsaeng-on (2016) conducted extensive research on talent and concluded that: "(1) Talent is defined as the sum of capability, commitment, loyalty, and contribution; (2) Talent is the combination of natural ability and nurture (acquired skills); and (3) Talent is managerial/key positions rather than all workers".

Overall, individuals who provide a straightforward contribution to a firm's strategy/goals and facilitate maintaining organizational competitiveness are considered talented employees (He, Li, \& Keung Lai, 2011). In defining talent, it is important to emphasize that companies also focus on the required characteristics of future employees, which vary widely from industry to industry, and identify talented individuals. It is not easy to select talent among all available employees since there are many ways to recognize talent, which can be defined in 


\section{Journal of Contemporary Management Issues}

terms of innate ability or achieving excellent performance (Tansley, 2011).

Achieving high performance entails three qualities that are inherent to talent: "competence $x$ commitment $x$ contribution" (Ulrich \& Smallwood, 2012). Competence pertains to an individual's entire knowledge, values, and skills, which are applied in their everyday work (McDonnell \& Collings, 2011). Commitment is another basic element of talent, which relates to the way, in which individuals implement diverse competencies and strong willingness in performing their work roles in the best possible way (Gallardo-Gallardo, Dries, \& Gonzalez-Cruz, 2013). Contribution relates to the value, arising from the use of required competencies and a high commitment in an individual's work role (McDonnell \& Collings, 2011).

Other authors argue that the universal characteristics of talent can be described with the acronym RAW (rewarding to deal with; able; willing to work hard) (Hogan, Chamorro-Premuzic, \& Kaiser, 2013). Michaels, Handfield-Jones, \& Axelrod (2001) classified talented employees into performance-based subgroups: "A-players" (high performers), "B-players" (medium performers), and "C-players" (low performers). According to these authors, "A-players" have twelve overall qualities (see Table 1).

Table 1. Quality of talent: „A-players“

\begin{tabular}{|c|c|}
\hline Dimension & Criteria \\
\hline „Overall talent level“ & „Top $10 \%$ of performance/potential workers“" \\
\hline „Vision" & $\begin{array}{l}\text { "Facilitates the creation and communication of a competing and strategically sound } \\
\text { vision" }\end{array}$ \\
\hline „Intelligence“ & „130 or higher IQ; „, a quick study“, able to rapidly perform complex analyses“" \\
\hline „Leadership“ & „Initiates change; highly adaptive and able to sell the organization changes" \\
\hline „Drive“ & „Passionate; extremely high energy level; fast-paced; $55+$ hour work per week" \\
\hline „Resourcefulness" & $\begin{array}{l}\text { „Impressive ability to find a way over, under, around, and barriers; invents new } \\
\text { paradigms“ }\end{array}$ \\
\hline „Customer focus“ & „Extremely sensitive and adaptive to both stated and unstated customer needs" \\
\hline „Coaching“ & $\begin{array}{l}\text { „Successfully counsels, mentors, and teaches each team member to „turbo-boost" } \\
\text { performance and personal/career growth" }\end{array}$ \\
\hline „Team building“ & „Creates focused, collaborative, result-driven teams; energizes other“ \\
\hline „Track record““ & „Exceeds expectations of employees, customers and shareholders“" \\
\hline „Integrity“ & „Ironclad““ \\
\hline „Communication“ & „Excellent oral/written skills“ \\
\hline
\end{tabular}

Source: Michaels, Handfield-Jones, \& Axelrod (2001)

An organization should possess the ability to recognize talents, which are appropriate for its requirements (Kaewsaeng-on, 2016). The talent criterion must be completely clear, before the beginning of the recruitment phase (Collings \& Mellahi, 2009).
This segmentation requires some ethical considerations that could emotionally impact employees in the sense of career development and organizational culture since incorrectly cultivated interpersonal relations can destroy organizational potential and its 
performance very quickly. Looking from the larger societal perspective, there are lots of ethical questions, which should be discussed, as demonstrated by the ongoing debate, regarding exclusive vs. inclusive talent management (Sparrow, 2019).

\subsection{The integrated process of talent management}

Talent management is a field, which attracts additional attention from academic researchers and practitioners in the HR and top management departments. Scullion, Collings, \& Caligiuri (2010) defined talent management in a very simplified manner, as "the need to identify, select, and develop the right people”. Additionally, Ruel \& Lake (2014) described talent management from a more comprehensive and global perspective, as the part of human resource management activities, which are directed towards identifying, attracting, developing, and retaining high-potential workers in the competitive environment on a worldwide scale. Therefore, talent management in contemporary business refers to the integrated process of attracting highly competent workers, the new effective ways of developing current workers (through training and advanced learning), and retaining all talented employees, by using efficient management and organization tools/approaches. Managing talents is of vital and core importance, not only for the individuals to show their potential and contribution to positive changes in an organization but also for the survival and sustainability of companies.

Besides attracting, constantly developing, and retaining talented employees, talent management also includes elements, such as motivation, managing the talent pool, improvement of productivity, rewarding and effective transferability of talents across the company. Prime talent retention has become a crucial challenge for firms that rely on knowledgeable human resources as their valuable intellectual capital (Srinivasan, 2011). The main emerging questions are: "Why is it so hard to keep employees to work for one company, and to stop them from constantly searching for better opportunities?" and "What lies behind that?". Successful organizations don't want to hire just for the sake of hiring but are trying to hire and retain the right employees, who can do the job with great results.

The purpose of talent management is not only to find and hire the perfect candidate but to continue with discovering their attributes and hidden abilities, as well as create employee development programs, by using a systematic approach. In addition, employees must be properly developed (trained/educated) and nurtured to achieve the best personal performance, as well as contribute to the best possible organizational performance. One of the fundamental goals is also to build a recognizable organizational culture and match talents to its culture, to make them work in a highly efficient and productive way. Within the global war for talents, all those activities do not provide any warranties that the highly skilled employees will stay long with it, as there is no undying loyalty in any organization, which is associated with cultural issues.

The fundamental elements of talent management are: attracting, developing, and retaining talent (Wahyuningtyas, 2015). Those three elements of talent management were explored in this research.

Attracting talent puts in front of an organization a hard task of clearly defining what it looks for, i.e. what qualities it needs from the potential high performers, where can it find desirable talents, and how those 


\section{Journal of Contemporary Management Issues}

can be assessed. Wahyuningtyas (2015) states that talent attraction consists of four elements: talent planning, recruitment, selection, and orientation. According to Abbas \& Cross (2018), recruitment from a talent pool, as one of the first and top tasks in the process of managing talents, implies creating a database of qualified and suitable candidates. Therefore, talent recruitment (internal or external) and selection is a vital priority for companies, wishing to maintain outstanding performance. Internal recruitment brings many benefits since employees are well acquainted with how their organization works and have a good understanding of its culture, which helps to build up employee morale in case of promotion (Davis, 2007). Nevertheless, the external sources are the most advantageous source of desirable talent, whenever organizations need to trigger innovation, creative thinking, and cultural change. Labor market competition requires the on-time recruitment process, with the proper usage of contemporary technological solutions and marketing approaches to recruitment (Slavić, Bjekić, \& Berber, 2017). Kellyservices (2013), in their survey of 100 firms, found that the primary elements of talent attraction are comprised of: benefits, wage packages, recruitment styles, company culture, social networking, work-life balance, and employee attrition. When it comes to the selection of applicants, the key recruiting managers in the company have to decide whom to choose. The most commonly used employee selection methods are ability tests, integrity tests, personality tests, group situational tests, work simulation tests, personal interviews, assessment centers, and references (Bogatova, 2017).

Many organizations, realizing how important skilled employees are to obtaining competitive advantage, frequently create a broad series of sophisticated practices and human resource development strategies to recognize, adequately develop and retain key talented employees (Wright \& McMahan, 2011; Connell \& Stanton, 2014). Talent development is directed towards enhancing the attitudes and skills of employees (Williamson, 2011). It is significant to emphasize that the right organizational support is needed, next to the talent desire to navigate their current/future development (Barlow, 2006). Such support encompasses the estimation of performance; mapping of talent; analysis of needs for learning/development; learning/development implementation and review of talents (Wahyuningtyas, 2015). It is of utmost importance to adjust workers' education and development to their behavior, work, and social values because each individual possesses a diverse personality and perception (Loke, Downe, Sambasivan, \& Khalid, 2012). Workers, who demonstrate a significant interest in following the organizational strategy and accomplishment of its goals, are highly developed and educated, as well as proactive, cooperative, communicative, able and willing to learn; customer-friendly, and respectful (Li, et al., 2009; Vnoučková, 2013).

Employee retention can be described as "an important ongoing process, in which the organization aims to retain employees for the maximum period or until the completion of the project" (Kaewsaeng-on, 2016). It further pertains to miscellaneous practices and policies that strengthen the long-term bond between an organization and employees (Kaewsaeng-on, 2016). According to Wahyuningtyas (2015), retaining talent includes planning their career, succession, and engagement. Each person has their value rating scale and distinct preferences. According to BahtijarevićŠiber (2014), knowing the real needs and preferences of employees is a basic prerequisite for creating an environment that can 
keep them. Some authors claim that monetary rewards represent key tools in talent retention (Vaiman \& Vance, 2010). Apart from the significance of financial rewards in retaining talent, Wubbe (2015) argues that it is also necessary to implement transparency in the business context, which includes keeping regular meetings and open communication, setting goals, and making decisions, based on collected feedback, as well as establishing consistent challenges to employees, in the context of their performance appraisals.

In this paper, the focus is placed on talent engagement, as one of the most important elements of talent retention, which is composed of five dimensions: "employee satisfaction, employee identification, employee commitment, employee loyalty and employee performance" (Kumar \& Pansari, 2015).

\subsection{Organisational performance}

Organizational performance is usually linked to business results, observed in different periods (weekly, monthly, or annually) in an observed organization. Daft (2000) depicted organizational performance in terms of abilities, needed for achieving the formulated goals, by using the available resources, in an appropriately structured way. In addition, Tomal \& Jones (2015) described the organizational performance in terms of the organization's actual results (output), measured against the organization's intended outputs. Bakotić (2016) used ten financial indicators for measuring performance: ongoing/total asset turnover, ROA, revenues/expenses ratio, return on capital employed (ROCE), return on equity (ROE), costs and revenue per worker, the BEX index value and earnings before taxes per employee. Conventional financial indicators are ordinarily linked to profitability, which is commonly used in performance assessment (Yalcin, Bayrakdaroglu, \& Kahraman, 2012). Lebans \& Euske (2006) suggested that profitability is the best indicator to determine, whether an organization can meet its goals. Organizational performance indicators, related to net profit and profit growth, have often been used in previous studies (e.g. Ndofor \& Priem, 2011). Putri \& Rahyuda (2020) argue that profit, as a fundamental goal of a company, also serves for benchmarking of important investors' decisions, while profit growth can be seen as an investment opportunity, which influences the increasing firm's value - due to amplified investors' confidence, which leads to higher demand and stock prices. Moreover, Sucuahi \& Cambarihan (2016) found that the relationship between profitability and firm value is positive and significant.

Gavrea, Ilies, \& Stegerean (2011) indicate that organizational performance involves three areas, related to an organization: (1) financial performance (including return on investments, profits, etc.), (2) shareholder return (including economic value-added, total shareholder return, etc.) and (3) the product/service market performance (including market share, sales, etc.). Sales growth is a highly significant measure of business success (Kotler, 2003), as it increases company value (Febriyanto, 2018). Sam \& Hoshino (2013) emphasize that "sales growth generally utilizes capacity more fully, which spreads fixed costs over more revenue resulting in higher profitability". These are the reasons for focusing research on profitability and sales growth as indicators of organizational performance in this study. 


\section{Journal of Contemporary Management Issues}

\subsection{Talent management and organizational performance}

Talented individuals, as a firm's strategic resource, lead companies to achieve superior performance. Certain authors have uncovered a positive and significant correlation between talent management, or some of its elements, and organizational performance. Dries (2013) points out that talent management programs lead toward accomplishing higher productivity, bigger profits, as well as to a noticeable contribution to competitive advantage. Sareen \& Mishra (2016) show in their research in the IT industry that talent management is positively related to the overall organizational performance, although with a partial impact of its practices on performance. Auranzeb $\&$ Bhutto (2016) found that, in the service sector firms, talent retention has been significantly linked to organizational performance. Glaister et. al. (2018) surveyed 198 respondent firms and concluded that, when talent management is focused on the development of social capital and workforce networks, it plays a vital role in mediating the relationship between human resource management and company performance. Kumar \& Pansari (2015) found that employee engagement can be linked to profit growth.

Kagwiria Lyria, Namusonge, \& Karanja (2017) demonstrated that diverse practices of talent management (such as practices, related to talent attraction, career management, learning/development, and talent retention) contribute positively to organizational performance.

\section{RESEARCH METHODOLOGY}

\subsection{Conceptual framework and research hypotheses}

The fundamental aim of this study is to examine the relationship between the talent management dimensions and the financial organizational performance in Bosnia and Herzegovina. A brief conceptual model is proposed as the basis for empirical research (see Figure 1).

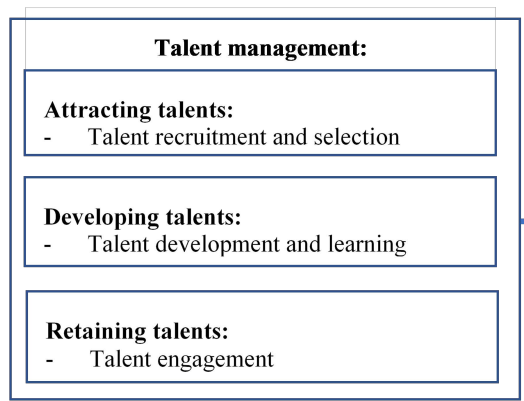

Figure 1. Conceptual framework

Figure 1 depicts two parts of the conceptual model: talent management and its influence on organizational performance. Talent management consists of the three main elements (Wahyuningtyas, 2015):
- Attracting talent (consists of ,talent planning, recruitment, selection, and orientation")

- Developing talent (encompasses „performance appraisal; talent mapping; development and learning need 
analysis; implementation of development and learning; and talent review")

- Retaining talent (includes ,career planning, succession planning, engaging talent")

In this study, the focus is placed on the fundamental categories of attracting talent (recruitment and selection), developing talent (development and learning implementation), and retaining talent (talent engagement). Talent recruitment and selection aim to discover crucial aspects of the first phase of the talent management system, related to the proactive build-up of the talent pools, recruitment marketing strategy, testing, and talent selection methods. Talent development aims to identify the way, in which talent education, training, and learning processes contribute to the overall organizational strategy. Talent engagement is conceptualized according to Kumar \& Pansari (2015), i.e. consisting of five dimensions: "employee satisfaction, employee identification, employee commitment, employee loyalty, and employee performance".

Financial indicators, used in this study, include profitability and sales growth. Based on the constructed model, the research hypotheses are identified as follows:

H1: There is a positive and statistically significant relationship between talent management and organizational performance, i.e. profit and sales growth.

$\mathrm{H} 2$ : Recruitment and selection have a positive and statistically significant influence on organizational performance.

H3: Talent development and learning have a positive statistically significant influence on organizational performance.

H4: Talent engagement has a positive and statistically significant influence on organizational performance.

\subsection{Methodological considerations}

This research uses quantitative analysis, while the data has been collected by using an appropriate questionnaire on talent management in companies, located in Bosnia and Herzegovina. The independent variables are the fundamental elements of talent management (attracting, developing, and retaining talent), while the dependent variables are indicators of organizational performance, which include profitability and sales growth. The research sample included the 97 key talented managers of enterprises, located in Bosnia and Herzegovina, who were selected, based on possessing three key qualities (Ulrich \& Smallwood, 2012).: required competencies, great commitment to work, and their excellent contribution to the work (someone who achieves the set results and often exceeds them). Human resource managers helped in the selection of surveyed talented managers since they had the necessary information available.

\subsection{Measures}

Scales for measuring the attraction and development of talent are constructed for this research. Both the talent attraction and the talent development scales consist of four items. Responses were presented on a five-point Likert-type scale, with the value of 1 denoting strong disagreement and the value of 5 strong agreement with the predefined items. Sample items for talent attraction are as follows: "Our company provides sufficiently attractive offer and salary for managerial positions" and "Our company uses, besides usual recruiting methods (like CV and interview), also additional testing for competency checking”. Sample items for developing talents included: "Our company invests in the development of talented managers and constant learning" and "Our company follows the newest trends 


\section{Journal of Contemporary Management Issues}

and applies the most efficient and effective training and educations for managers". For the dimension of talent retaining, the measure, consisting of 20 items, previously developed by Kumar \& Pansari (2015), was used to evaluate talent engagement, which consists of five sub-categories: talent satisfaction, talent identification, talent commitment, talent loyalty, and talent performance. Talents were asked to rate their experience with the current organization on a five-point scale $(1=$ the lowest score; $5=$ the highest score). The sample items are as follows: "I feel good about working at this company" (one of the talent satisfaction items); and "I view the success of the brand as my own" (one of the talent identification items).
The reliability of all three addressed scales has been evaluated by using the Cronbach alpha indicator (see Table 1). Analysis of internal consistency disclosed that the value of Cronbach alpha for the constructs used is as follows: 0.851 for attracting talent $(\mathrm{N}=4), 0.879$ for developing talent $(\mathrm{N}=4)$, and 0.964 for talent engagement, as the fundamental element of talent retention $(\mathrm{N}=20)$. Each construct in the model had the value of Cronbach's $\alpha$ higher than 0.7 , showing that talent attraction, talent development, talent retention, and organizational performance have relatively high internal consistency.

Table 1. Reliability statistics

\begin{tabular}{|l|l|l|}
\hline Variables & Number of items & Cronbach Alpha \\
\hline Attracting talent (Talent recruitment and selection) & 4 & 0.851 \\
\hline Developing talent & 4 & 0.879 \\
\hline Retaining talent (Talent engagement) & 20 & 0.964 \\
\hline
\end{tabular}

\section{RESEARCH RESULTS}

Collected data were analyzed by using descriptive statistics. Pearson correlation coefficient, regression analysis, and the ANOVA test of the multiple linear regression model.

Table 2. Structure of the sample

\begin{tabular}{|l|l|c|}
\hline \multirow{2}{*}{ Gender } & Male & $43 \%$ \\
& Female & $57 \%$ \\
\hline \multirow{5}{*}{ Age } & $20-30$ years & $33 \%$ \\
& $31-40$ years & $40 \%$ \\
& $41-50$ years & $17 \%$ \\
\hline \multirow{5}{*}{ Level of education } & $51-60$ years & $8 \%$ \\
& Over 60 years & $2 \%$ \\
\hline & High school & $6 \%$ \\
& Bachelor degree & $29 \%$ \\
& Master degree & $60 \%$ \\
& PhD & $5 \%$ \\
\hline
\end{tabular}

\subsection{Structure of the sample}

The survey was conducted through faceto-face interviews, during 2019, with a total of 97 respondents, from all parts of Bosnia and Herzegovina (see Table 2). 


\begin{tabular}{|l|l|c|}
\hline & Director/general manager & $18 \%$ \\
& Branch manager & $13 \%$ \\
Managerial position & Sales manager & $27 \%$ \\
& Project manager & $26 \%$ \\
& Financial Manager & $9 \%$ \\
& Other types of manager & $7 \%$ \\
\hline
\end{tabular}

The sample consisted of slightly more female $(57 \%)$ than male talented managers (43\%). Furthermore, respondents mostly belonged to the group of young and middle-aged adults $(73 \%$ of respondents were in the age group between 20 and 40 years, $17 \%$ of managers were between the age of 41 and $50.8 \%$ were older adults (between the age of 51 and 60 years) and $2 \%$ were over 60 . The majority of talented managers had a university degree $(60 \%$ of managers had a master's degree, $29 \%$ bachelor's degree, and 5\% a Ph.D. degree), while some of the talents $(6 \%)$ had only a high school diploma. Most of the talents (27\%) worked as sales managers and $26 \%$ as project managers. A large group of talents occupied higher managerial positions $(18 \%$ were general managers, and $13 \%$ were branch managers), $9 \%$ of talents worked as financial managers, and 7\% were involved in other managerial duties.

\subsection{Correlations}

This study analyzes the relationship between talent recruitment and selection, talent development and learning, and talent engagement with organizational performance, measured by sales growth and profitability growth. The Pearson correlation matrix is presented in Table 3. Results of the correlation analysis show that a positive and statistically significant correlation exists among all the variables, implying that the talent management practice leads to improvement of organizational performance in companies in Bosnia and Herzegovina.

The correlation values of 0.461 and 0.452 show the existence of a significant, but moderate relationship between talent recruitment and selection and organizational performance (measured by sales and profitability growth). Regarding talent development and learning and sales growth, the correlation value of 0.538 also shows a significant and moderate relationship. Similar results are found when analyzing the relationship of talent development and learning with profitability growth, where the correlation is, also, significant and of moderate strength $(\mathrm{r}=0.566)$. When it comes to talent engagement and organizational performance, the correlation between talent engagement and sales growth has the value of 0.724 , and the correlation between talent engagement and profitability growth the value of 0.728 . These variables are significantly and strongly correlated with one another (see Table 3 ). These correlations serve as a foundation for subsequent modeling of regression relationships, resulting in a better understanding of causal relationships between the analyzed variables. 


\section{Journal of Contemporary Management Issues}

Table 3. Pearson correlation matrix for talent management and organizational performance variables

\begin{tabular}{|l|c|c|c|}
\hline & $\begin{array}{c}\text { Talent recruitment } \\
\text { and selection }\end{array}$ & $\begin{array}{c}\text { Talent development } \\
\text { and learning }\end{array}$ & $\begin{array}{c}\text { Talent } \\
\text { engagement }\end{array}$ \\
\hline Sales growth & $.461^{* *}$ & $.538^{* *}$ & $.724^{* *}$ \\
\hline Profitability growth & $.452^{* *}$ & $.566^{* *}$ & $.728^{* *}$ \\
\hline
\end{tabular}

Note: ${ }^{* *}$ Correlation is significant at the 0.01 level (2-tailed).

\subsection{Multiple linear regression}

Multiple linear regression is applied in this study to evaluate the strength and direction of causal relationships between the independent variables (talent attraction, talent development and learning, and talent retention) and the dependent variable (organizational performance: sales growth and profitability growth). Regression outcomes are presented in Table 4., indicating a satisfactory fit for the regression of talent management independent variables and organizational performance.

Table 4. Model fit for organizational performance

\begin{tabular}{|l|c|c|c|c|}
\hline Model & R & R square & Adjusted R square & Std. Error of the estimate \\
\hline 1 & $.968^{\mathrm{a}}$ & .937 & .931 & .782 \\
\hline
\end{tabular}

Predictors: (Constant), Talent Recruitment and Selection, Talent Development and Learning, Talent Engagement

Results in Table 4 indicate the existence of a relationship between talent recruitment and selection, talent development and learning, talent engagement, and organizational performance, as demonstrated by the value of $\mathrm{R}=0.968$. The value of the adjusted $\mathrm{R}$ square is 0.931 , showing that $93.1 \%$ of the variance in organizational performance can be explained by the predictors of talent recruitment and selection, talent development, and learning and talent engagement.
Table 5. Shows results of the ANOVA test. The overall model was statistically significant, i.e. independent variables were good joint explanatory determinants of organizational performance $(\mathrm{F}=129,887$ and the statistical significance of 0.000 ). It is important to emphasize that the $\mathrm{F}$ calculated value $(129,887)$ exceeds the $F$ critical value $(17,837)$, which confirms that the overall model is statistically significant.

Table 5. ANOVA test (model significance)

\begin{tabular}{|c|c|c|c|c|c|}
\hline & Sum of Squares & df & Mean Square & $\mathbf{F}$ & Sig. \\
\hline Regression & 1271,851 & 16 & 79,491 & 129,887 & $.000^{\mathrm{b}}$ \\
\hline Residual & 49,548 & 81 & 0,612 & & \\
\hline Total & & 97 & & & \\
\hline \multicolumn{6}{|c|}{ a. Dependent variable: Organisational Performance } \\
\hline \multicolumn{6}{|c|}{$\begin{array}{l}\text { Predictors: (Constant), Talent Recruitment and Selection, Talent Development and Learning, Talent } \\
\text { Engagement }\end{array}$} \\
\hline
\end{tabular}


Table 5. shows that the value of statistical significance is .000 , and the score assumes a value smaller than .05 . Therefore, the $\mathrm{F}$ test is considered to be significant, so the null hypothesis may be discarded and a claim can be made that the regression model may be used to explain changes in the research population. Table 6 shows the coefficients of the regression model, where all predictors have a positive and significant influence on organizational performance.

Table 6. Regression model coefficients

\begin{tabular}{|l|l|l|l|l|l|}
\hline \multirow{2}{*}{ Predictors } & \multicolumn{2}{|l|}{ Unstandardized Coefficients } & $\begin{array}{l}\text { Standardized } \\
\text { Coefficients }\end{array}$ & t & \multirow{2}{*}{ Sig. } \\
\cline { 2 - 5 } & $\mathbf{B}$ & Std. Error & Beta & & \\
\hline (Constant) & .247 & .056 & & 4.411 & .001 \\
\hline Talent recruitment and selection & .261 & .033 & .194 & 7.909 & .000 \\
\hline Talent development and learning & .315 & .039 & .281 & 8.077 & .000 \\
\hline Talent engagement & .489 & .045 & .372 & 10.867 & .000 \\
\hline Dependent variable: Organisational Performance \\
\hline
\end{tabular}

With the values of $\beta=0.261$ and $p=.000$ for talent recruitment and selection, each single unit change of independent variable brings about the 0.261 unit change of organizational performance, while keeping other variables constant. For the explanatory variable, related to talent development and learning, $\beta=0.315$ and $p=.000$, i.e. for each unit change of talent development and learning, there is a 0.315 unit change of organizational performance, while keeping other variables constant. For the third independent variable - talent engagement, $\beta=0.489$ and $p=.000$, i.e. for each single unit change of talent engagement, there is a 0.489 unit change of organizational performance, while keeping other variables constant.

The t-value for every single regression coefficient in the presented model appraises whether the talent management dimensions are significant predictors of organizational performance. Considering that $\mathrm{t}=7.909$ and $\mathrm{p}=0.000<0.05$, it can be concluded that talent recruitment and selection are significant predictors of better organizational performance. Talent development and learning are, also, significant predictors of enhanced organizational performance (since $\mathrm{t}=8.077$ and $p=0.000<0.05$ ). Talent engagement, as the third talent management dimension, is also a significant predictor of organizational performance $(\mathrm{t}=10.867$ and $\mathrm{p}=0.000<0.05)$ in companies in Bosnia and Herzegovina.

The empirical results support the main research hypothesis of a positive and statistically significant relationship between talent management and organizational performance. Furthermore, results show the importance of talent management for companies in developing countries, such as Bosnia and Herzegovina. Regarding talent attraction (talent recruitment and selection), this study shows that companies in Bosnia and Herzegovina use additional testing as a selection method for checking the key competencies. In addition, they provide sufficiently attractive offers and salaries to talented managers, which affects organizational performance positively. When it comes to talent development and learning, the study confirms that the responding companies invest in talent development and constant learning, as well as apply efficient and effective training/education methods for talented managers, which positively 


\section{Journal of Contemporary Management Issues}

contributes to organizational performance. Results, related to talent engagement, as the main part of talent retention, demonstrate that talented managers are satisfied with the job and the employer, identify with their organization and its success, are truly committed and loyal, as well as exceed their goals, which further positively affects organizational performance (measured by profitability growth and sales growth).

\section{LIMITATIONS AND FURTHER RESEARCH DIRECTIONS}

This study has certain limitations. The first limitation is found in the fact that it did not take into consideration some external influences on talent management practices and organizational performance. In addition, the sample is rather small and was not divided into categories, according to the type of the business and the industry sector. The second limitation is a simplification of relations between variables, avoiding the use of structural and cultural components of an organization, as variables, mediating the relationship between talent management and business performance. Some additional limitations are connected to the psychological and other traits of respondents, which were not taken into consideration.

Directions for further research in this field in Bosnia and Herzegovina could include testing the influence of different organizational structures, in terms of their size, age, strategy, power, technology, and culture, as mediators between talent management application and business performance. Additional research directions should consider larger sample sizes, which will help to get more precise data and more reliable results, which could be, additionally, considering some of the main psychological traits of respondents.

\section{RECOMMENDATIONS}

This study, conducted in Bosnia and Herzegovina, contributes to understanding talent management, concerning business performance, in general. It might lead to additional research in this multidisciplinary field, by using a background from different scientific areas, since human resource management in general and especially talent management, should be analyzed by using holistic and multidisciplinary approaches. This study also contributes to raising awareness of how essential and valuable talents are for overall business success and how hard it is to find and retain them. Enterprises in developing countries need to make talent management their strategic priority and invest in talents' learning, development, and satisfactory motivation, as the entire organization grows and learns with them, by sharing knowledge and leading by example. Finally, research on talent development and talent management is scarce in developing countries, which has been recognized by our literature review

Practical aspects of this research can explain differences between the business performance of the companies depending on their leadership, human resources management, and people development practices, with the specific emphasis on talent management. Research results also provide direction to policy-makers, as related to developing specific social and economic measures, decreasing the trend of the human drain in general and, more specifically, the brain drain from the developing countries. 


\section{CONCLUSION}

Contemporary organizations of all sizes and types compete for different resources to survive and prosper on competitive and complex markets. One of the most important forms of competition is for the desired talents in the labor market. Talents are individuals with superior capabilities and competencies, who are wholeheartedly committed to doing the work most efficiently and effectively, contributing enormously to excellent organizational performance. To get the right talents and attract them to the company, and even more importantly, to retain talents in the long-term as the firm's core strengths, requires an exquisite talent management strategy.

In this exploratory study, an analysis of the talent management influence on organizational performance in companies in Bosnia and Herzegovina has been conducted. Talent management is viewed as the effort of an enterprise to attract, develop and retain talented managers. When it comes to organizational performance, two of its components were considered: profitability and sales growth. Results show that all three talent management components have a positive and statistically significant influence on the firm's organizational performance. This study shows that a systematic approach to talent recruitment, development, and retention leads to better business performance. Finally, companies in developing countries must understand that the most important resources are highly committed managers at all organizational levels, as the most responsible individuals for business success, although they must not neglect to cultivate talent management with all employees, as a foundation for developing the internal human resources strategy and maintaining the recruitment base.

\section{REFERENCES}

1. Abbas, U., \& Cross, O. (2018). Talent management and its effects on the competitive advantage in organizations. International Journal of Recent Advances in Multidisciplinary Research, 5(11), 4247-4253.

2. Armstrong, M., \& Taylor, S. (2014). Armstrong's Handbook of Human Resource Management Practice. Kogan Page Publishers.

3. Aswathappa, K. (2010). Human Resource Management. Text and Cases. New Delhi: Tata Mcgraw Hill.

4. Auranzeb, \& Bhutto, S. (2016). Influence of talent management in enhancing organisation performance (Evidence from service sector companies in Pakistan). Industrial Engineering Letters, 6(6), 49-55.

5. Bahtijarević-Šiber, F. (2014). Strateški menadžment ljudskih potencijala: Suvremeni trendovi i izazovi. Zagreb: Školska knjiga.

6. Bakotić, D. (2016). Relationship between job satisfaction and organisational performance. Economic Research - Ekonomska istraživanja, 29.

7. Balbuena Aguenza, B., \& Puad Mat Som, A. (2012). Motivational Factors of Employee Retention and Engagement in Organizations. International Journal of Advances in Management and Economics, 1(6), 88-95.

8. Barlow, L. (2006). Talent development: the new imperative? Development and Learning in Organizations: An International Journal, 20(3), 6-9.

9. Berger, L., \& Berger, D. (2011). Designing and assembling the building blocks for organisation excellence: the talent management model. In L. 


\section{Journal of Contemporary Management Issues}

Berger, \& D. Berger (Eds.), The Talent Management Handbook: Creating a Sustainable Competitive Advantage by Selecting, Developing and Promoting the Best People (1-2). London: McGraw-Hill Education.

10. Bogatova, M. (2017). Thesis: Improving recruitment, selection and retention of employees; Case: Dpointgroup Ltd.

11. Boston Consulting Group. (2018). Decoding Global Talent. Retrieved from https://www.bcg.com/publications/collections/decoding-global-talent on January 26, 2019

12. Chamorro-Premuzic, T., Winsborough, D., Sherman, R., \& Hogan, R. (2016). New Talent Signals: Shiny New Objects or a Brave New World? Industrial and Organizational Psychology, 9(3), 621-640.

13. Collings, D., \& Mellahi, K. (2009). Strategic talent management: A review and research agenda. Human Resource Management Review, 19(4), 304-313.

14. Connell, J., \& Stanton, P. (2014). Skills and the Role of HRM: Towards a Research Agenda for the Asia Pacific Region. Asia Pacific Journal of Human Resources, 52(1), 4-22.

15. Daft, L. R. (2000). Organisation Theory and Design (7th Ed.). Cincinnati $(\mathrm{OH})$ : South-Western College Publishing.

16. Davis, T. (2007). Talent assessment: a new strategy for talent management. Farnham: Gower Publishing Ltd.

17. Devins, D., Gold J., (2014). Reconceptualising Talent Management and Development within the Context of the Low Paid. Human Resource Development International, 17(1), 514-528.
18. Dries, N. (2013). The psychology of talent management: A review and research agenda. Human Resource Management Review, 23(4), 272-285.

19. Fajčikova, A., Fejfarova, M., Urbancova H., (2016). Employee Development by Talent Management Implementation, Scientific Papers of the University of Pardubice, 38(3), 18-30.

20. Febriyanto, F. (2018). The effect of leverage, sales growth and liquidity to the firm value of real estate and property sector in Indonesia stock exchange. EAJ - Economics and Accounting Journal, 1(3), 198-205.

21. Gallardo-Gallardo, E., Dries, N., \& Gonzalez-Cruz, T. (2013). What is the meaning of talent in the world of work? Human Resource Management Review, 23(4), 290-300.

22. Gavrea, C., Ilies, L., \& Stegerean, R. (2011). Determinants of organizational performance: The case of Romania. Management \& Marketing, 6(2), 285-300.

23. Glaister, A., Karacay, G., Demirbag, M., \& Tatoglu, E. (2018). HRM and performance-The role of talent management as a transmission mechanism in an emerging market context. Human Resource Management Journal, 28(1), 148-166.

24. Guthridge, M., Komm, A., \& Lawson, E. (2008). Making talent a strategic priority. McKinsey Quarterly, 1(1), 49-59.

25. He, Y., Li, W., \& Keung Lai, K. (2011). Service climate, employee commitment and customer satisfaction. International Journal of Contemporary Hospitality Management, 23(5), 592-607.

26. Hogan, R., Chamorro-Premuzic, T., \& Kaiser, R. (2013). Employability 
Management, Vol. 26, 2021, No. 1, pp. 129-147 E. Čizmić, A. Ahmić: THE INFLUENCE OF TALENT MANAGEMENT ON ORGANISATIONAL ...

and Career Success: Bridging the Gap Between Theory and Reality. Industrial and Organizational Psychology, 6(1), 3-16.

27. Horwitz, F., Budhwar, P., \& Morley, M. (2015). Future trends in human resource management in the emerging markets. In F. Horwitz, \& P. Budhwar (Eds), Handbook of Human Resource Management in the Emerging Markets. Cheltenham: Edward Elgar Publishing.

28. Kaewsaeng-on, R. (2016). PhD. Thesis: Talent management: a critical investigation in the Thai hospitality industry. Retrieved fromhttps:// usir.salford.ac.uk/id/eprint/39105/1/ RudsadaKaewsaeng-on.pdf

29. Kagwiria Lyria, R., Namusonge, G., \& Karanja, K. (2017). Role of talent management on organization performance in companies listed in Nairobi securities exchange in Kenya. Journal of Human Resource and Leadership, 1(3), 1-17.

30. Kaliannan, M., \& Narh Adjovu, S. (2015). Wining the Talent War via Effective Employee Engagement: A Case Study. Journal of Business \& Financial Affairs, 3(3), 1-7.

31. Kellyservices. (2013). Attraction and Retention of Talent. Retrieved from Kellyservices.co.nz.

32. Kotler, P. (2003). Marketing Management. (11th Ed.). New Jersey: Prentice-Hall.

33. Kumar, V., \& Pansari, A. (2015). Measuring the Benefits of Employee Engagement. MIT Sloan Management Review, 56(4), 66-72.

34. Lanvin, B., \& Evans, P. (2017). The Global Talent Competitiveness Index. Fontainebleau: INSEAD Business School, Adecco Group and Human Capital Leadership Institute.
35. Lebans, M., \& Euske, K. (2006). A conceptual and operational delineation of performance. Business Performance Measurement: Theory and Practice, 1, 65-79.

36. Li, J., Brake, G., Champion, A., Fuller, T., Gabel, S., \& Hatcher-Busch, L. (2009). Workplace learning: the roles of knowledge accessibility and management. Journal of Workplace Learning, 21(4), 347-364.

37. Loke, S., Downe, A., Sambasivan, M., \& Khalid, K. (2012). A structural approach to integrating total quality management and knowledge management with supply chain learning. Journal of Business Economics and Management, 13(4), 776-800.

38. Lynton, N., \& Beechler, S. (2012). Using Chinese Managerial Values to Win the War for Talent. Asia Pacific Business Review, 18(4), 567-585.

39. ManpowerGroup. (2018). Solving the Talent Shortage: Build, Buy, Borrow and Bridge. Retrieved from https://go.manpowergroup.com/hubfs/TalentShortage \%202018\%20 (Global)\%20Assets/PDFs/MG TalentShortage2018_10\%206_25_18_ FINAL.pdf

40. McDonnell, A., \& Collings, D. (2011). The identification and evaluation of talent in MNEs. In H. Scullion, \& D. Collings (Eds.), Global Talent Management. Abingdon: Routledge.

41. Michaels, E., Handfield-Jones, H., \& Axelrod, B. (2001). War for Talent. Boston: Harvard Business School Press.

42. Morley, M., Scullion, H., Collings, D., \& Schuler, R. (2015). Talent management: a capital question. European Journal of International Management, 9(1), 1-8. 


\section{Journal of Contemporary Management Issues}

43. Ndofor, H., \& Priem, R. (2011). Immigrant entrepreneurs, the ethnic enclave strategy, and venture performance. Journal of Management, 37, 790-818.

44. Putri, I., \& Rahyuda, H. (2020). Effect of capital structure and sales growth on firm value with profitability as mediation. International Research Journal of Management, IT and Social Sciences, 7(1), 145-155.

45. Ruel, H.J.M., \& Lake, C. (2014). Global Talent Management in MNCs in the Digital Age: Conceptualizing the GTM-ICT Relationship. In $\mathrm{T}$. Bondarouk \& M.R. Olivas-Lujan (Eds.), Human Resource Management, Social Innovation and Technology (Advanced Series in Management, 14, 155-178). Bingley: Emerald Group Publishing Limited.

46. Sageer, A., Rafat, S., \& Agarwal, P. (2012). Identification of Variables Affecting Employee Satisfaction and Their Impact on the Organization. Journal of Business and Management, 5(1), 32-39.

47. Sam, M., \& Hoshino, Y. (2013). Sales growth, profitability and performance: empirical study of Japanese ICT industries with three ASEAN countries. Interdisciplinary Journal of Contemporary Research in Business, 4(11), 138-156.

48. Sareen, P., \& Mishra, S. (2016). A study of talent management and its impact on performance of organizations. Journal of Business and Management, 18(12), 66-73.

49. Scullion, H., Collings, D.G., \& Caligiuri, P. (2010). Global talent management. Journal of World Business, 45(2), 105-108.
50. Slavić, A., Bjekić, R., \& Berber, N. (2017). Uloga interneta i društvenih mreža u procesu regrutacije i selekcije. In A. Grubor (Ed.), Strategijski menadžment $i$ sistemi podrške odlučivanju u strategijskom menadžmentu (88-96). Subotica: Ekonomski fakultet u Subotici.

51. Sparrow, P., (2019). A Historical Analysis of Critiques in the Talent Management Debate. Business Research Quarterly, 21(1), 161-170.

52. Srinivasan, M. S. (2011). An Integral Approach to Talent Management. Vilakshan: The XIMB Journal of Management, 8(2), 81-90.

53. Sucuahi, W., \& Cambarihan, J. (2016). Influence of profitability to the firm value of diversified companies in the Philippines. Accounting and Finance Research, 5(2), 149-153.

54. Tansley, C. (2011). What do we mean by the term talent in talent management? Industrial and Commercial Training, 43(5), 266-274.

55. Tomal, D., \& Jones, K. (2015). A comparison of core competencies of women and men leaders in the manufacturing industry. The Coastal Business Journal, 14(1), 13-25.

56. Ulrich, D., \& Smallwood, N. (2012). What is talent? Leader to Leader, 63, 55-61.

57. Vaiman, V., \& Vance, C. (2010). Smart talent management: building knowledge assets for competitive advantage. Cheltenham: Edward Elgar Publishing.

58. Vnoučková, L. (2013). Fluktuace a retence zaméstnanců. Prague: Adart.

59. Wahyuningtyas, R. (2015). An integrated talent management system: challenges for competitive advantage. International Business Management, 9(4), 384-390. 
60. Williamson, D. (2011). Talent management in the new business world: How companies can create the future and not be consumed by it. Human Resource Management International Digest, 19(6), 33-36.

61. World Economic Forum. (2017). The Global Human Capital Report 2017. Retrieved from https://www.weforum.org/reports/ the-global-human-capital-report-2017

62. Wright, P., \& McMahan, G. (2011). Exploring human capital: putting human back into human resource management. Human Resource Management Journal, 21(2), 93-104.

63. Wubbe, E. (2015). Attracting and retaining top talent. The Secured Lender, 71(4), 20-23.

64. Yalcin, N., Bayrakdaroglu, A., \& Kahraman, C. (2012). Application of Fuzzy Multi-Criteria Decision Making Methods for Financial Performance Evaluation of Turkish Manufacturing Industries. Expert Systems with Applications, 39(1), 350-364.

\title{
UTJECAJ UPRAVLJANJA TALENTIMA NA ORGANIZACIJE PERFORMANSE U BOSNI I HERCEGOVINI KAO ZEMLJI U RAZVOJU
}

\begin{abstract}
Sažetak
Poduzeća na današnjem, globaliziranom, brzo promjenjivom i digitaliziranom tržištu trebaju talente, koji, osim temeljnih vještina, posjeduju i više razine, kao i optimalnu kominaciju različitih kompetencija i kvalifikacija. Privlačenje najboljih zaposlenika, njihov razvoj i zadržavanje predstavlja ključni čimbenik uspjeha za bilo koje poduzeće i zahtijeva dobro postavljeno upravljanje talentima. Ovaj rad se usmjerava na analizu utjecaja menadžmenta talenata, promatranog kroz njegovo privlačenje, razvoj $i$ zadržavanje, na unapređenje performansi poduzeća u Bosni i Hercegovini. Podaci su prikupljeni korištenjem upitnika, kojim su obuhvaćeni ključni

elementi upravljanja talentima i organizacijskih performansi (na području profitabilnosti i rasta prodaje), u populaciji talentiranih menadžera, koji rade u BiH poduzećima. S obzirom da su talentirani menadžeri ključni strateški resurs, koji vodi organizacije prema postizanju izvrsnih performansi, poduzeća u zemljama u razvoju trebaju formulirati efikasne i prilagođene strategije upravljanja talentima, s ciljem stalnog unapređenja organizacijskih ishoda.

Ključne riječi: privlačenje talenata, razvoj talenata, angažiranje talenata, organizacijske performanse
\end{abstract}

